\title{
Iatrogenic Injury Due to Transverse Colon Vascular Compromise, As an Uncommon Cause of Acute Abdomen, Case Report
}

Luis Vega*, Sergi Sánchez, Kevin Oh-Uiginn and Daiva Luckute

Department of General Surgery and Digestive Diseases, Hospital of Igualada, Spain

Submission: March 01, 2019; Published: March 12, 2019

*Corresponding author: Luis Vega, Department of General Surgery and Digestive Diseases, Hospital of Igualada, Spain

\section{Objective}

To expose an infrequent cause of colon perforation.

Materials and Methods

Case handled by our service and bibliographic review.

\section{Clinical Case}

A 65-year-old woman with controlled hypertension, with a history of gynecological surgery: Hysterectomy with adnexectomy, pelvic lymphadenectomy, appendectomy and omentectomy, for uterine body neoplasia (anatomopathological analysis reported Serous Papillary Carcinoma). The patient presented pain and abdominal distension, fever, tachycardia and analytical elevation of acute phase reactants at 36 hours postoperatively. Abdominal computed tomography was performed in which the presence of extraluminal gas (pneumoperitoneum) was observed (Figure 1). We carried out an open approach identifying segmental ischemia of the colon circumscribed to the transverse colon (Figure 2); we carried out resection of this segment and manual anastomosis, favorable postoperative course, with discharge to the $8^{\text {th }}$ day post-reoperation [1-8].

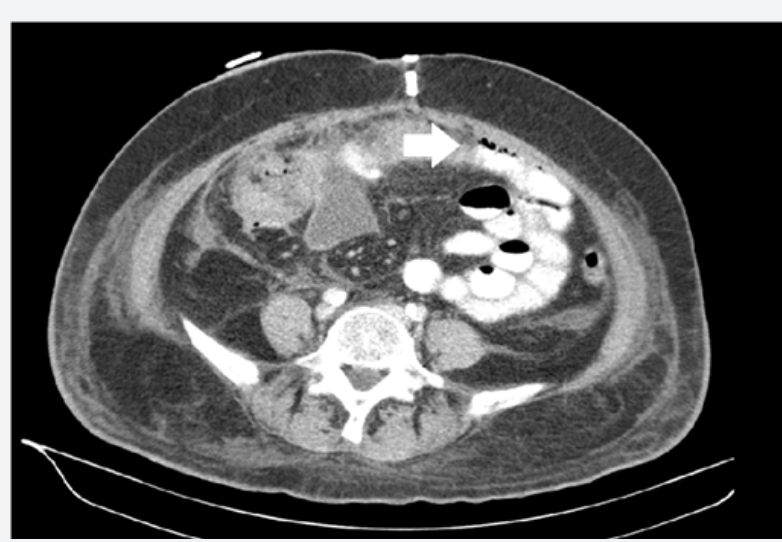

Figure 1: Abdominal computed tomography was performed in which the presence of extraluminal gas (pneumoperitoneum) was observed.

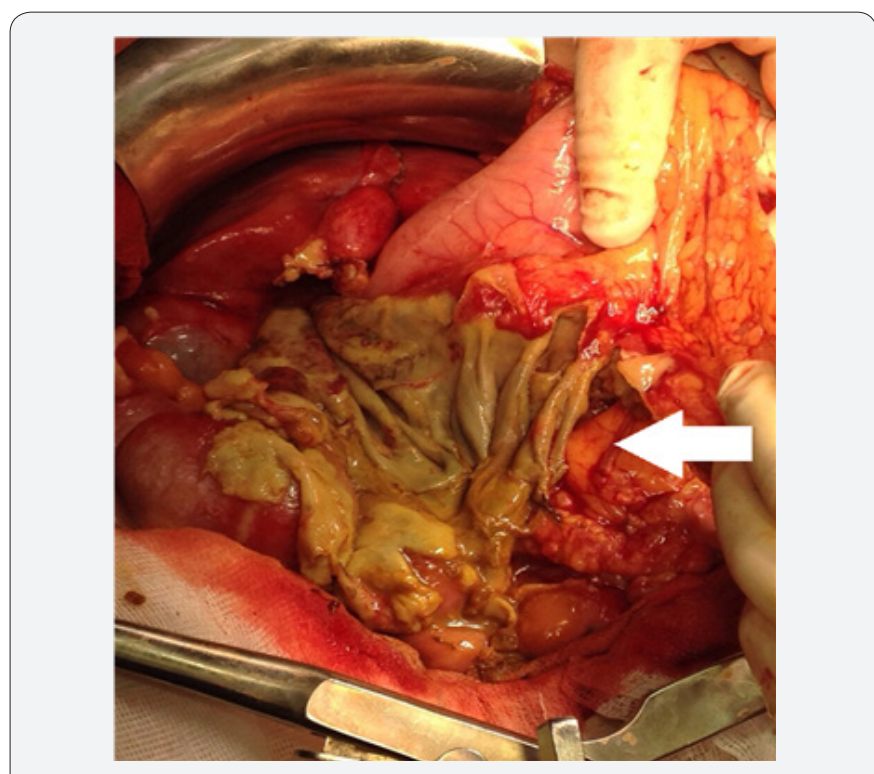

Figure 2: We carried out an open approach identifying segmental ischemia of the colon circumscribed to the transverse colon.

\section{Discussion}

Ischemic lesion of the transverse colon of iatrogenic origin is an infrequent entity, although with a high morbimortality. The radiological test of choice is the abdominal computed tomography (CT), the surgical technique will depend on the intraoperative findings. The presence of this complication is a representative example of the importance of correct identification of anatomical planes between the omentum and the transverse mesocolon, quite possibly the segmental ischemia presented by this patient corresponds to an inadvertent vascular lesion of the middle colic artery.

\section{References}

1. Trenti L, Biondo S, Golda T, Monica M, Kreisler E, et al. (2011) Generalized peritonitis due to perforated diverticulitis: Hartmann's procedure or primary anastomosis? Int J Color Dis 26(3): 377-384. 
2. Zorcolo L, Covotta L, Carlomagno N, Bartolo DCC (2003) Safety of primary anastomosis in emergency colo-rectal surgery. Color Dis 5(3): 262-269.

3. Hinchey EJ, Schaal PG, Richards GK (1978) Treatment of perforated diverticular disease of the colon. Adv Surg 12: 85-109.

4. Constantinides VA, Heriot A, Remzi F, Darzi A, Senapati A, et al. (2007) Operative strategies for diverticular peritonitis: a decision analysis between primary resection and anastomosis versus Hartmann's procedures. Ann Surg 245(1): 94-103.

5. Dindo D, Demartines N, Clavien PA (2004) Classification of surgical complications: a new proposal with evaluation in a cohort of 6336 patients and results of a survey. Ann Surg 240(2): 205-213.
6. Bridoux V, Regimbeau JM, Ouaissi M, Mathonnet M, Mauvais F, et al. (2017) Hartmann's procedure or primary anastomosis for generalized peritonitis due to perforated diverticulitis: a prospective multicenter randomized trial (DIVERTI). J Am Coll Surg 225(6): 798-805.

7. Freund MR, Goldin I, Reissman P (2018) Superior Mesenteric Vein Injury During Oncologic Right Colectomy: Current Vascular Repair Modalities. Vasc Endovascular Surg 52(1): 11-15.

8. Cho HS, Woo JY, Hong HS, Park MH, Ha HI, et al. (2013) Multidetector CT findings of bowel transection in blunt abdominal trauma. Korean journal of radiology 14(4): 607-615.

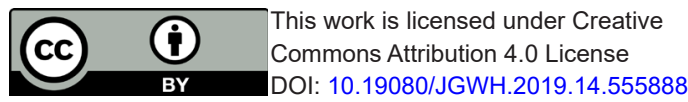

\section{Your next submission with Juniper Publishers will reach you the below assets}

- Quality Editorial service

- Swift Peer Review

- Reprints availability

- E-prints Service

- Manuscript Podcast for convenient understanding

- Global attainment for your research

- Manuscript accessibility in different formats ( Pdf, E-pub, Full Text, Audio)

- Unceasing customer service

Track the below URL for one-step submission https://juniperpublishers.com/online-submission.php 